\title{
Quelle visibilité professionnelle pour un salarié ambassadeur 2.0 auprès des recruteurs potentiels?
}

Valérie Larroche

\section{OpenEdition}

\section{Journals}

Édition électronique

URL : http://journals.openedition.org/communicationorganisation/4309

DOI : 10.4000/communicationorganisation.4309

ISSN : $1775-3546$

Éditeur

Presses universitaires de Bordeaux

Édition imprimée

Date de publication : 1 décembre 2013

Pagination : 53-64

ISBN : 978-2-86781-878-3

ISSN : 1168-5549

\section{Référence électronique}

Valérie Larroche, «Quelle visibilité professionnelle pour un salarié ambassadeur 2.0 auprès des

recruteurs potentiels ? », Communication et organisation [En ligne], 44 | 2013, mis en ligne le 01

décembre 2016, consulté le 19 avril 2019. URL : http://journals.openedition.org/

communicationorganisation/4309; DOI : 10.4000/communicationorganisation.4309 
